\title{
Risk of Cancer in Patients with Psoriasis on Biological Therapies: A Systematic Review
}

DOI:

10.1111/bjd. 15830

\section{Document Version}

Accepted author manuscript

Link to publication record in Manchester Research Explorer

\section{Citation for published version (APA):}

Peleva, E., Exton, L., Kelley, K., Kleyn, C., Mason, K., \& Smith, C. H. (2018). Risk of Cancer in Patients with Psoriasis on Biological Therapies: A Systematic Review. British Journal of Dermatology, 178(1).

https://doi.org/10.1111/bjd.15830

\section{Published in:}

British Journal of Dermatology

\section{Citing this paper}

Please note that where the full-text provided on Manchester Research Explorer is the Author Accepted Manuscript or Proof version this may differ from the final Published version. If citing, it is advised that you check and use the publisher's definitive version.

\section{General rights}

Copyright and moral rights for the publications made accessible in the Research Explorer are retained by the authors and/or other copyright owners and it is a condition of accessing publications that users recognise and abide by the legal requirements associated with these rights.

\section{Takedown policy}

If you believe that this document breaches copyright please refer to the University of Manchester's Takedown Procedures [http://man.ac.uk/04Y6Bo] or contact uml.scholarlycommunications@manchester.ac.uk providing relevant details, so we can investigate your claim.

\section{OPEN ACCESS}


DR EMILIA PELEVA (Orcid ID : 0000-0002-1783-9860)

Article type : Systematic Review

Risk of Cancer in Patients with Psoriasis on Biologic Therapies: A Systematic Review

Running head: Cancer Risk with Biologic Drugs for Psoriasis

Authors: E. Peleva ${ }^{1}$, L.S. Exton ${ }^{2}$, K. Kelley ${ }^{3}$, K.J. Mason ${ }^{4,5}$, C.H. Smith ${ }^{1,5}$

\section{Affiliations:}

${ }^{1}$ St John's Institute of Dermatology. Guy's and St Thomas' NHS Foundation Trust, London, UK

${ }^{2}$ British Association of Dermatologists, London, UK

${ }^{3}$ National Clinical Guidelines Centre, London, UK

${ }^{4}$ Division of Musculoskeletal and Dermatological Sciences, The University of Manchester, Manchester, UK

${ }^{5}$ Joint senior authors

Corresponding author: Catherine H. Smith

E-mail: catherine.smith@kcl.ac.uk

\section{Funding sources:}

The research was funded/supported by the National Institute for Health Research (NIHR) Biomedical Research Centre based at Guy's and St Thomas' NHS Foundation Trust and King's College London, and by the British Association of Dermatologists (BAD). The views expressed are those of the author(s) and not necessarily those of the NHS, the BAD, the NIHR or the Department of Health.

This article has been accepted for publication and undergone full peer review but has not been through the copyediting, typesetting, pagination and proofreading process, which may lead to differences between this version and the Version of Record. Please cite this article as doi: $10.1111 /$ bjd. 15830

This article is protected by copyright. All rights reserved. 


\section{Conflict of Interest:}

KJM received honoraria from Eli Lilly and Janssen. CHS received departmental research funding from Pfizer, Abbvie, Janssen, Novartis. CHS is PI on MRC funded stratified medicine consortium which has a number of industry partners (www.PSORT.org.uk). The other authors state no conflict of interest.

\section{What's already known about this topic?}

- The risk of cancer in biologic-exposed psoriasis patients is poorly understood. While the risk is reasonably well-characterized in other chronic autoimmune conditions, these findings cannot be extrapolated to psoriasis patients.

\section{What does this study add?}

- This systematic review summarizes the current literature for cancer risk in biologicexposed psoriasis patients. Signals are emerging that exposure to tumor necrosis factor inhibitors is associated with an increased risk of non-melanoma skin cancers in people with psoriasis, but comparator groups identified were historic and studies lack adjustment for highly relevant confounding factors such as prior phototherapy. Longterm pharmacovigilance is still required to establish whether there is a risk of cancer directly attributable to biologic therapy.

\section{Summary}

Biologic therapies are highly effective in psoriasis, but have profound effects on innate and adaptive immune pathways that may negatively impact on cancer immunosurveillance mechanisms. To investigate the risk of cancer in psoriasis patients treated with biologic therapy we searched Medline, Embase, and the Cochrane Library (up to August 2016) for randomized control trials, prospective cohort studies and systematic reviews that reported 
cancer incidence in people exposed to biologic therapy for psoriasis compared to a control population. Eight prospective cohort studies met our inclusion criteria. All the evidence reviewed related to tumour necrosis factor inhibitors (TNFi) with the exception of one study on ustekinumab. An increased risk of non-melanoma skin cancer (NMSC), particularly squamous cell carcinoma, was reported with TNFi compared to both a general United States population and a rheumatoid arthritis population treated with TNFi. No evidence for increased risk of cancers (reported as all cancers, lymphoma, melanoma, prostate, colorectal and breast cancer) other than NMSC was identified. There were important limitations to the studies identified including choice of comparator arms, inadequate adjustment for confounding factors and failure to account for latency periods of cancer. There remains a need for ongoing pharmacovigilance in relation to cancer risk and biologic therapy; to determine whether the NMSC signal is specifically attributable to TNFi, further investigation is required using prospectively-collected data with adjustment for known NMSC risk factors. Systematic review registration number: PROSPERO; 2015:CRD42015017538

\section{Introduction}

Biologic agents licensed for the use in psoriasis include tumour necrosis factor inhibitors (TNFi; etanercept, infliximab, and adalimumab), and antagonists of the interleukin (IL)-17 pathway (ustekinumab, secukinumab and ixekizumab) (1). Real-world data accumulated from pharmacovigilance registries show these agents to be generally well-tolerated and effective in clinical practice (2-5). However, biologic therapies have profound effects on innate and adaptive immune pathways that may be relevant to cancer immunosurveillance mechanisms, with the TNFi in particular targeting an established major cytokine in cancer pathways (6).

This article is protected by copyright. All rights reserved. 
Prospective cohort studies in other immune-mediated inflammatory diseases (e.g. rheumatoid arthritis $(7,8)$ and psoriatic arthritis (9)) provide some reassurance regarding risk of cancer following treatment with biologics although these findings may not be generalizable to psoriasis. Increased rates of cancer including non-melanoma skin cancers (NMSC), lymphoma, and colorectal cancers have been reported in psoriasis per se (10) and so establishing risk specifically attributable to biologic therapies is not straightforward. 'Generic' population risk factors, such as demographics (age, ethnicity, family or personal history of cancer), obesity, smoking, or alcohol excess need to be taken into account. Disease-specific factors are also relevant: for example, maladaptive coping mechanisms may be associated with more smoking and alcohol excess (11). Most patients receiving biologic therapies for psoriasis will have had prior exposure to 'non-biologic' systemic immunosuppression, and of relevance to skin cancer, phototherapy, all of which may drive risk $(12,13)$.

To date, psoriasis treatment guidelines have provided recommendations based on the theoretical concerns about risk of cancer $(14,15)$. These aim to protect patients but may be limiting access for those who are perceived to be at risk (17). Given that biologic agents have been in use for over 15 years $(16,17)$ and considering the latency period for developing a cancer, it is reasonable to review the evidence for long-term risk of cancer now. We have therefore performed a systematic review to investigate the risk of cancer in psoriasis patients who have specifically been treated with biologics, focussing on studies with a defined comparator arm and follow-up of at least 6 months. This review informed the updated British Association of Dermatologists guidelines for use of biologic therapies in psoriasis $[\mathrm{Br}]$ Dermatol. 2017 May 17. doi: 10.1111/bjd.15665. [Epub ahead of print]

This article is protected by copyright. All rights reserved. 


\section{Materials and methods}

The review was conducted in accordance with the Preferred Reporting Items for Systematic Reviews and Meta-Analyses (PRISMA) statement. The review protocol was registered on the International Prospective Register of Systematic Reviews (PROSPERO; 2015:CRD42015017538).

Predefined search strategy and selection criteria

An a priori protocol was established as follows (complete protocol in Supplementary material, S1):

The objective was to determine the risk of cancer in people with psoriasis (all phenotypes) exposed to biologic therapies. The outcome of interest was incidence of any cancer in studies with follow-up of $\geq 6$ months using the initiation of biologic treatment or a reference starting time-point. Data for different cancers were summarised separately (NMSC, melanoma, lymphoma, and solid cancer).

The primary population included all patients with psoriasis treated with biologics. Only studies with a comparator arm were included. Analysis by strata (cancers and psoriatic arthritis) and confounding factors considered for sub-group analysis are described in Supplementary material, S1.

Systematic reviews, randomized controlled trials (RCTs), open-label extension (OLE) studies, and prospective cohort studies on any biologic were included. Studies with indirect populations were excluded; populations where the proportion being treated primarily for psoriatic arthritis was greater that $50 \%$ were considered indirect.

This article is protected by copyright. All rights reserved. 


\section{Search and Study Selection}

The systematic literature search was performed in Medline, Embase, and the Cochrane Library from inception until August 2016, with the results de-duplicated, titles reviewed and irrelevant studies excluded by an information scientist (LE). The search strategy and search terms are available in Supplements S2.1-2.3. Studies reported in languages other than English were excluded.

The abstracts were screened by two assessors (LE and EP), and disagreements resolved by a third (CS). The full-text articles were obtained and checked against the protocol and those that did not meet the criteria were excluded (LE, CS and EP). Reference lists of systematic reviews and meta-analyses were screened for additional papers (LE and EP).

\section{Data Extraction and Quality Assessment}

Data extraction and appraisal was performed using a standardized template (EP) and repeated by a second researcher (LE) and differences were resolved by a third independent assessor (CS). Data collected included: study details (study type, data source, setting, duration of study, funding sources), population details (disease severity, subgroup analysis, number of groups/participants, selection criteria, age, gender, ethnicity, exposure to previous phototherapy, previous immunosuppression, comorbidities including smoking and alcohol, psoriatic arthritis, body weight, previous cancers, family history of cancers), interventions, and results (type and number of cancers, when these developed).

The methodological quality was assessed for individual studies using the Cochrane Collaboration's tool for assessing risk of bias (18). Adjustment for or consideration of potential confounders was also evaluated.

This article is protected by copyright. All rights reserved. 


\section{Data Analysis}

Where possible, meta-analyses were planned. If not appropriate, descriptive statistics were used to summarize the data.

\section{Results}

The systematic literature search yielded 4566 results after duplicates were removed (Figure 1). Of these, 245 abstracts were screened, and 63 full-text articles were assessed for eligibility. Seventeen additional papers were identified through hand-searching reference lists of systematic reviews. Data were extracted from eight prospective cohort studies that met the inclusion criteria. The studies and reasons for exclusion are listed in Supplement S3. In summary, reasons for study exclusion were lack of a comparator arm $(n=26)$, duplicate publication $(n=20)$, follow-up less than 6 months $(n=7)$, no extractable data $(n=10)$, indirect populations $(n=4)$, retrospective design $(n=1)$, out of scope $(n=3$, one study was on tildrakizumab, two did not look at biologics), or study was withdrawn $(n=1)$.

[Fig.1]

\section{Risk of bias}

Using the Cochrane Collaboration's tool for assessing risk of bias, the overall risk of bias for all of the studies was rated as very high (Table 1) (18). Risk of selection bias was low in 7/8 $(88 \%)$ studies; it was graded high in van Lumig as data collected from hospital registries risks missing some events due to misclassification and there is a potential risk of surveillance bias (19). Given that the outcome is objective, the risk of performance bias was low in all studies. The risk of attrition bias was high for all studies.

This article is protected by copyright. All rights reserved. 
Risk of detection or measurement bias was high in $7 / 8$ studies. Research was funded by pharmaceutical companies $(n=7)$ or it was not reported $(n=1)$. The outcome was defined as patients with cancer $(n=3)(20-22)$, as cancers $(n=2)(23,24)$, or both $(n=3)(19,25,26)$. The quality of the evidence across all studies was very low, due to the high risk of bias.

The studies could not be pooled for a meta-analysis due to differences in the biologic therapies investigated, variable exposure lengths, variable outcome definitions, incomplete data and no adequate control for key confounding factors, other than age and sex. The data were therefore summarized using descriptive statistics.

\section{Confounding factors}

Confounding factors were either poorly reported or not reported. No studies reported skin type. In the 6 studies that reported ethnicity, over $80 \%$ of patients were Caucasian (range 81.1\%-96.4\%; Table 2) (20-22, 24-26).

Sex- and age-matched comparison cohorts were used in 7/8 studies; adjustment for age or sex, or for other confounders, were not reported in Pariser et al. (Table 2) (26). van Lumig et al. adjusted for multiple confounders (19), but it is unclear whether the remaining six studies adjusted for the confounding factors (Table 2).

\section{Study characteristics}

The main study characteristics are summarised in Table 3, including: RCTs or OLEs $(n=6)$; a post-marketing surveillance registry $(\mathrm{n}=1)$; and prospective registries from medical centres $(n=1)$. The studies included between 280 to 4410 patients located in North America $(n=2)$, Europe $(n=1)$, or internationally $(n=5)$. Patients in the intervention groups received etanercept ( $n=3$ studies), infliximab $(n=1)$, adalimumab $(n=2)$, multiple TNFi class $(n=1)$, or 
ustekinumab $(n=1)$. Studies included patients with plaque-type psoriasis only $(n=6)$, or it was not reported $(n=2)$, and disease severity was moderate-to-severe on the Physician Global Assessment scale in most studies. The majority of patients were male $(52.4 \%$ to $68.5 \%)$, and the mean age ranged from 44 to 47 years.

A variety of comparator arms were used. Six studies investigating any cancers excluding NMSC used the United States (US) National Cancer Institute (NCI) Surveillance, Epidemiology, and End Results (SEER) database; four studies used data recorded between 1992-2003 (23-26), and two studies did not report the time period used (Table 3) (21, 22). In order to investigate the risk of NMSCs specifically, four of these studies obtained incidence rates from the 1977-1978 NCI Survey $(23,24)$ and the South-eastern Arizona Skin Cancer Registry and Rochester Epidemiology Project in Minnesota $(25,26)$ as comparator arms (Table 3). One study used US patients who received methotrexate and/or ciclosporin for other unspecified inflammatory conditions identified through insurance claims databases as the comparator arm for all outcomes; in van Lumig et al., the intervention (psoriasis patients) and comparator arms (rheumatoid arthritis) exposed to TNFi were identified from two hospital registries (19) (Table 3).

All of the studies included a biologic cohort of psoriasis patients with mixed prior exposure to biologics, conventional systemics and/or phototherapy; none of the studies included a biologic-naïve comparator arm of psoriasis patients.

This article is protected by copyright. All rights reserved. 


\section{Risk of cancers}

\section{(i) Any Cancers}

Compared to the general US population, standardized incidence ratios (SIRs) show no increased risk in psoriasis patients of 'any cancers excluding NMSC' with TNFi therapies or ustekinumab (Table 4). There was no increased risk with etanercept compared to patients on non-biological systemic therapies for other inflammatory conditions (conditions not reported).

\section{(ii) Skin Cancers}

Four studies investigated the risk of NMSC in psoriasis patients on TNFi therapies (Table 4). In the two studies reporting data on adalimumab, there was an increased risk of NMSC compared to the general US population (SIR 1.76, 95\% confidence interval (CI) 1.26-2.39 and SIR 1.51, 95\% CI 1.04-2.11) $(23,24)$. We believe there is considerable overlap in the data presented in these studies based on the number of trials and patients reported, despite marginal differences in the reported results. Consistent with the previous findings, an increased risk of NMSC was reported in patients receiving TNFi for psoriasis compared to those with rheumatoid arthritis (adjusted hazard ratio 6.0, 95\% CI 1.6-22.4 and adjusted risk ratio 5.5, 95\% CI 2.2-13.4) (19). This risk may be driven by an increase in SCC with increases reported with both etanercept (SIR 1.78, 95\% CI 1.11-2.69 and SIR 4.28, 95\% CI 2.68,-6.47) and adalimumab (SIR 3.84, 95\% CI 1.54-7.92) compared to a general US population $(24,26)$. Only one study specifically evaluated the risk of melanoma in those receiving ustekinumab, and found no increased incidence compared to a general US population (Table 4).

This article is protected by copyright. All rights reserved. 
(iii) Solid cancers and Lymphoma

SIRs showed no increased incidence of prostate, colorectal or breast cancer for ustekinumab compared to the general US population. SIRs for lymphoma demonstrated no increased risk; however, fewer than 5 events were reported for psoriasis patients exposed to etanercept (20), adalimumab (23) and ustekinumab (22). The median follow-up for studies evaluating risk of lymphoma was only 0.5 years for adalimumab, and 5-7 years for etanercept and ustekinumab (Table 4). The incidence of lymphoma was 0.11 and 0.13 per 1000 person years for etanercept and ustekinumab, respectively.

\section{Discussion}

This systematic review provides an up-to-date synthesis of the published evidence regarding the risk of cancer with biologic therapies in psoriasis patients and is the first to specifically address the long-term incidence of cancer in this population. The most significant finding in this review is the increased risk of NMSC, associated with exposure to TNFi. This risk appears to be driven by an increase in SCC, which is consistent with findings observed with non-biologic 'immunosuppression' $(12,13)$. However, there are important limitations to the design and reporting of the included studies that make it difficult to be certain that this signal is specifically attributable to biologic therapy.

Firstly, the comparator arms are problematic. As psoriasis patients who were exposed to nonbiologic therapies were not included in any comparator arms, it is impossible to determine whether the incidence rates of cancer were further elevated following exposure to biologics (10). For NMSC incidence, studies included the 1977-8 NCI-SEER survey $(23,24)$, and the 1985-1996 Arizona and 1984-1992 Minnesota registries (25, 26). Not only do these general population cohorts fail to account for confounders present in the psoriasis population (including phototherapy and conventional systemic therapies), but these cohorts are also not 
contemporaneous with the cohorts of biologic-exposed psoriasis patients. NMSC incidence has significantly increased over time, as demonstrated by incidence rates in Germany more than doubling between 1998 (43/100,000 population) and 2010 (105/100,000 population) (27). Comparing NMSC risks at distinct time points may lead to inflated risk estimates.

Secondly, two of the studies compared the overall incidence of cancer in the intervention group (ie: multiple cancers per patient), to the incidence of first-time diagnosis of cancer in the comparison cohort $(23,24)$. Therefore the increased SIRs for NMSCs may be related to overestimating incidence by counting the number of cancers.

Thirdly, the studies did not adequately control for key confounders other than age and sex (including previous phototherapy, prior exposure to immunosuppression, and previous NMSCs) $(13,28)$. Outcomes were not separately reported for patients who had a history of cancer, and only one study corrected for history of previous NMSC (19). Clinical trials have historically excluded patients with history of cancer; six studies present data from RCTs and open-label studies, and at least one excluded patients with history of cancer as above (19), while the other studies do not report full exclusion criteria. In van Lumig, although the authors correct for confounders, they do not correct for UV exposure (Table 2). This could partly explain the high adjusted hazard ratio and risk ratio for NMSC (29).

Whilst the data on the risk of cancers other than NMSC in the present review are reassuring, the studies are likely to be underpowered to ascertain the risk of other solid cancers, and particularly the risk of lymphoma following exposure to TNFi. In common with the data on NMSC, most studies used the general population as a comparison cohort, and adjustment for confounding factors was inadequate.

A number of other aspects make interpretation of findings difficult. Confounding by indication (prognostic factors that may bias prescribing) is problematic for two of the eight studies identified $(19,20)$; excess alcohol and current smoking are factors that may influence 
clinician choice of which treatment to prescribe a patient. Also, the psoriasis patients included in the identified studies were recruited from diverse geographical areas, which potentially influences baseline risk of cancer, the likelihood of seeking treatment, how events are reported, and how patients are treated. These factors, alone or in combination, further complicate interpretation of risk estimates: in relation to NMSC for example, there is regional variation in use of PUVA and natural sun exposure as a treatment for psoriasis.

Latency periods were not investigated in any of the included studies. Most cancers develop over a long period of time and so it is unlikely that biologic therapy initiated close to a diagnosis of cancer is causally related. The 8 studies identified include all cancers since the initiation of treatment with only three studies providing information on when the cancers developed $(19,20,26)$. None of the included studies summarised the length of time between a previous cancer and initiating biologic therapy. Follow-up time, which may have an effect on the incidence of cancers reported, is highly variable among and within studies. Patients often did not complete the planned duration of treatment or follow up, and three studies only included cancers that developed during treatment and up to 30-70 days after treatment was discontinued $(23,24,26)$.

In conclusion, studies show an increased risk of NMSC, especially SCC, with the TNFi therapies etanercept and adalimumab, compared to the general US population. The evidence to date suggests that there is no increased risk of cancers other than NMSC. There is however no 'real world' evidence and there are significant limitations to the studies identified with the data largely from relatively short-term RCT and OLE studies, making it difficult to extrapolate to real-world practice. There is therefore a continuing need for pharmacovigilance.

This article is protected by copyright. All rights reserved. 
Based on an estimated cancer frequency of 1 in 500 in patients only exposed to conventional systemic therapies and a recruitment rate of 2:1 (biologic-exposed : biologic-naïve), 18,250 and 9,125 person years of follow-up, respectively, would be needed to detect a two-fold increase in the risk of cancer (30); if the cancer frequency is rarer (1 in 1000), the person years of follow-up would increase to 36,550 for biologic-exposed and 18,275 for biologicnaïve patients. The detail and scale of the data capture within ongoing pharmacovigilance registries, such as the British Association of Dermatologists Biologic Interventions Register (BADBIR) (30) as well as collaborative efforts through Psonet (4), offer the opportunity to investigate cancer risk; specifically, the risk attributable to biologic therapy compared with patients only exposed to conventional systemic therapies and phototherapies. In order to determine whether there is a real increased risk of NMSC with biologic therapies, analyses need to take into account key confounders prevalent in the population (including excess alcohol and smoking) and the timing of events in relation to starting biologic therapies, and should report outcomes both as events and patients with events.

\section{Acknowledgments}

This systematic review was supported by the British Association of Dermatologists to inform the next update to the clinical guidelines for biologic therapy for psoriasis. We are grateful to Dr M. Firouz Mohd Mustapa, British Association of Dermatologists, London, for his advice and assistance.

This article is protected by copyright. All rights reserved. 


\section{References}

1. Jabbar-Lopez Z, Yiu ZZ, Exton L, Mustapa FM, Samareskera E, Burden AD, Murphy R, Owen C, Warren RB, Smith CH. Quantitative Evaluation of Biologic Therapy Options for Psoriasis: A Systematic Review and Network Meta-Analysis. Journal of Investigative Dermatology. 2017.

2. Gottlieb AB, Kalb RE, Langley RG, Krueger GG, de Jong EM, Guenther L, et al. Safety observations in 12095 patients with psoriasis enrolled in an international registry (PSOLAR): experience with infliximab and other systemic and biologic therapies. Journal of drugs in dermatology : JDD. 2014;13(12):1441-8. Epub 2015/01/22.

3. Driessen RJ, Boezeman JB, van de Kerkhof PC, de Jong EM. Three-year registry data on biological treatment for psoriasis: the influence of patient characteristics on treatment outcome. The British journal of dermatology. 2009;160(3):670-5. Epub 2009/02/13.

4. Garcia-Doval I, Cohen AD, Cazzaniga S, Feldhamer I, Addis A, Carretero G, et al. Risk of serious infections, cutaneous bacterial infections, and granulomatous infections in patients with psoriasis treated with anti-tumor necrosis factor agents versus classic therapies: Prospective meta-analysis of Psonet registries. Journal of the American Academy of Dermatology. 2017;76(2):299-308 e16. Epub 2016/10/04.

5. Warren RB, Smith CH, Yiu ZZ, Ashcroft DM, Barker JN, Burden AD, et al. Differential Drug Survival of Biologic Therapies for the Treatment of Psoriasis: A Prospective Observational Cohort Study from the British Association of Dermatologists Biologic Interventions Register (BADBIR). The Journal of investigative dermatology. 2015;135(11):2632-40. Epub 2015/06/09.

6. Aggarwal BB, Shishodia S, Sandur SK, Pandey MK, Sethi G. Inflammation and cancer: how hot is the link? Biochemical pharmacology. 2006;72(11):1605-21. Epub 2006/08/08.

7. Mercer LK, Askling J, Raaschou P, Dixon WG, Dreyer L, Hetland ML, et al. Risk of invasive melanoma in patients with rheumatoid arthritis treated with biologics: results from a 
collaborative project of 11 European biologic registers. Annals of the rheumatic diseases. 2017;76(2):386-91. Epub 2016/06/17.

8. Mercer LK, Lunt M, Low AL, Dixon WG, Watson KD, Symmons DP, et al. Risk of solid cancer in patients exposed to anti-tumour necrosis factor therapy: results from the British Society for Rheumatology Biologics Register for Rheumatoid Arthritis. Annals of the rheumatic diseases. 2015;74(6):1087-93. Epub 2014/04/02.

9. Hellgren K, Dreyer L, Arkema EV, Glintborg B, Jacobsson LT, Kristensen LE, et al. Cancer risk in patients with spondyloarthritis treated with TNF inhibitors: a collaborative study from the ARTIS and DANBIO registers. Annals of the rheumatic diseases. 2017;76(1):105-11. Epub 2016/05/06.

10. Pouplard C, Brenaut E, Horreau C, Barnetche T, Misery L, Richard MA, et al. Risk of cancer in psoriasis: a systematic review and meta-analysis of epidemiological studies. Journal of the European Academy of Dermatology and Venereology : JEADV. 2013;27 Suppl 3:3646. Epub 2013/07/17.

11. Nelson PA, Keyworth C, Chisholm A, Pearce CJ, Griffiths CE, Cordingley L, et al. 'In someone's clinic but not in mine'--clinicians' views of supporting lifestyle behaviour change in patients with psoriasis: a qualitative interview study. The British journal of dermatology. 2014;171(5):1116-22. Epub 2014/07/02.

12. Archier E, Devaux S, Castela E, Gallini A, Aubin F, Le Maitre M, et al. Carcinogenic risks of psoralen UV-A therapy and narrowband UV-B therapy in chronic plaque psoriasis: a systematic literature review. Journal of the European Academy of Dermatology and Venereology : JEADV. 2012;26 Suppl 3:22-31. Epub 2012/05/26.

13. Marcil I, Stern RS. Risk of developing a subsequent nonmelanoma skin cancer in patients with a history of nonmelanoma skin cancer: a critical review of the literature and meta-analysis. Archives of dermatology. 2000;136(12):1524-30. Epub 2000/12/15.

This article is protected by copyright. All rights reserved. 
14. Smith CH, Anstey AV, Barker JN, Burden AD, Chalmers RJ, Chandler DA, et al. British Association of Dermatologists' guidelines for biologic interventions for psoriasis 2009. The British journal of dermatology. 2009;161(5):987-1019. Epub 2009/10/28.

15. American Academy of Dermatology Work G, Menter A, Korman NJ, Elmets CA, Feldman SR, Gelfand JM, et al. Guidelines of care for the management of psoriasis and psoriatic arthritis: section 6. Guidelines of care for the treatment of psoriasis and psoriatic arthritis: case-based presentations and evidence-based conclusions. Journal of the American Academy of Dermatology. 2011;65(1):137-74. Epub 2011/02/11.

16. Mease PJ, Goffe BS, Metz J, VanderStoep A, Finck B, Burge DJ. Etanercept in the treatment of psoriatic arthritis and psoriasis: a randomised trial. Lancet. 2000;356(9227):38590. Epub 2000/09/06.

17. Chaudhari U, Romano P, Mulcahy LD, Dooley LT, Baker DG, Gottlieb AB. Efficacy and safety of infliximab monotherapy for plaque-type psoriasis: a randomised trial. Lancet. 2001;357(9271):1842-7. Epub 2001/06/19.

18. Higgins JPT, Altman, D.G., Sterne, J.A.C. Chapter 8: Assessing risk of bias in included studies. Version 5.1.0 ed. Higgins JPT, Green, S., editor. www.handbook.cochrane.org: The Cochrane Collaboration; 2011 March 2011.

19. van Lumig PP, Menting SP, van den Reek JM, Spuls PI, van Riel PL, van de Kerkhof PC, et al. An increased risk of non-melanoma skin cancer during TNF-inhibitor treatment in psoriasis patients compared to rheumatoid arthritis patients probably relates to disease-related factors. Journal of the European Academy of Dermatology and Venereology : JEADV. 2015;29(4):752-60. Epub 2014/09/18.

20. Kimball AB, Rothman KJ, Kricorian G, Pariser D, Yamauchi PS, Menter A, et al. OBSERVE-5: observational postmarketing safety surveillance registry of etanercept for the treatment of psoriasis final 5-year results. Journal of the American Academy of Dermatology. 2015;72(1):115-22. Epub 2014/09/30.

This article is protected by copyright. All rights reserved. 
21. Menter A, Reich K, Gottlieb AB, Bala M, Li S, Hsu MC, et al. Adverse drug events in infliximab-treated patients compared with the general and psoriasis populations. Journal of drugs in dermatology : JDD. 2008;7(12):1137-46. Epub 2009/01/14.

22. Papp KA, Griffiths CE, Gordon K, Lebwohl M, Szapary PO, Wasfi Y, et al. Longterm safety of ustekinumab in patients with moderate-to-severe psoriasis: final results from 5 years of follow-up. The British journal of dermatology. 2013;168(4):844-54. Epub 2013/01/11.

23. Burmester GR, Panaccione R, Gordon KB, McIlraith MJ, Lacerda AP. Adalimumab: long-term safety in 23458 patients from global clinical trials in rheumatoid arthritis, juvenile idiopathic arthritis, ankylosing spondylitis, psoriatic arthritis, psoriasis and Crohn's disease. Annals of the rheumatic diseases. 2013;72(4):517-24. Epub 2012/05/09.

24. Leonardi C, Papp K, Strober B, Reich K, Asahina A, Gu Y, et al. The long-term safety of adalimumab treatment in moderate to severe psoriasis: a comprehensive analysis of all adalimumab exposure in all clinical trials. American journal of clinical dermatology. 2011;12(5):321-37. Epub 2011/08/13.

25. Papp KA, Poulin Y, Bissonnette R, Bourcier M, Toth D, Rosoph L, et al. Assessment of the long-term safety and effectiveness of etanercept for the treatment of psoriasis in an adult population. Journal of the American Academy of Dermatology. 2012;66(2):e33-45. Epub 2010/09/21.

26. Pariser DM, Leonardi CL, Gordon K, Gottlieb AB, Tyring S, Papp KA, et al. Integrated safety analysis: short- and long-term safety profiles of etanercept in patients with psoriasis. Journal of the American Academy of Dermatology. 2012;67(2):245-56. Epub $2011 / 10 / 22$.

27. Rudolph C, Schnoor M, Eisemann N, Katalinic A. Incidence trends of nonmelanoma skin cancer in Germany from 1998 to 2010. Journal der Deutschen Dermatologischen Gesellschaft $=$ Journal of the German Society of Dermatology : JDDG. 2015;13(8):788-97. Epub 2015/07/28.

This article is protected by copyright. All rights reserved. 
28. Scott FI, Mamtani R, Brensinger CM, Haynes K, Chiesa-Fuxench ZC, Zhang J, et al. Risk of Nonmelanoma Skin Cancer Associated With the Use of Immunosuppressant and Biologic Agents in Patients With a History of Autoimmune Disease and Nonmelanoma Skin Cancer. JAMA dermatology. 2016;152(2):164-72. Epub 2015/10/29.

29. Garcia-Doval I, Hernandez MV, Vanaclocha F, Sellas A, de la Cueva P, Montero D, et al. Should tumour necrosis factor antagonist safety information be applied from patients with rheumatoid arthritis to psoriasis? Rates of serious adverse events in the prospective rheumatoid arthritis BIOBADASER and psoriasis BIOBADADERM cohorts. The British journal of dermatology. 2016. Epub 2016/06/04.

30. Burden AD, Warren RB, Kleyn CE, McElhone K, Smith CH, Reynolds NJ, et al. The British Association of Dermatologists' Biologic Interventions Register (BADBIR): design, methodology and objectives. The British journal of dermatology. 2012;166(3):545-54. Epub $2012 / 02 / 24$.

This article is protected by copyright. All rights reserved. 


\section{Figures}

Figure 1- Flow chart of the selection of articles using the 2009 PRISMA statement format

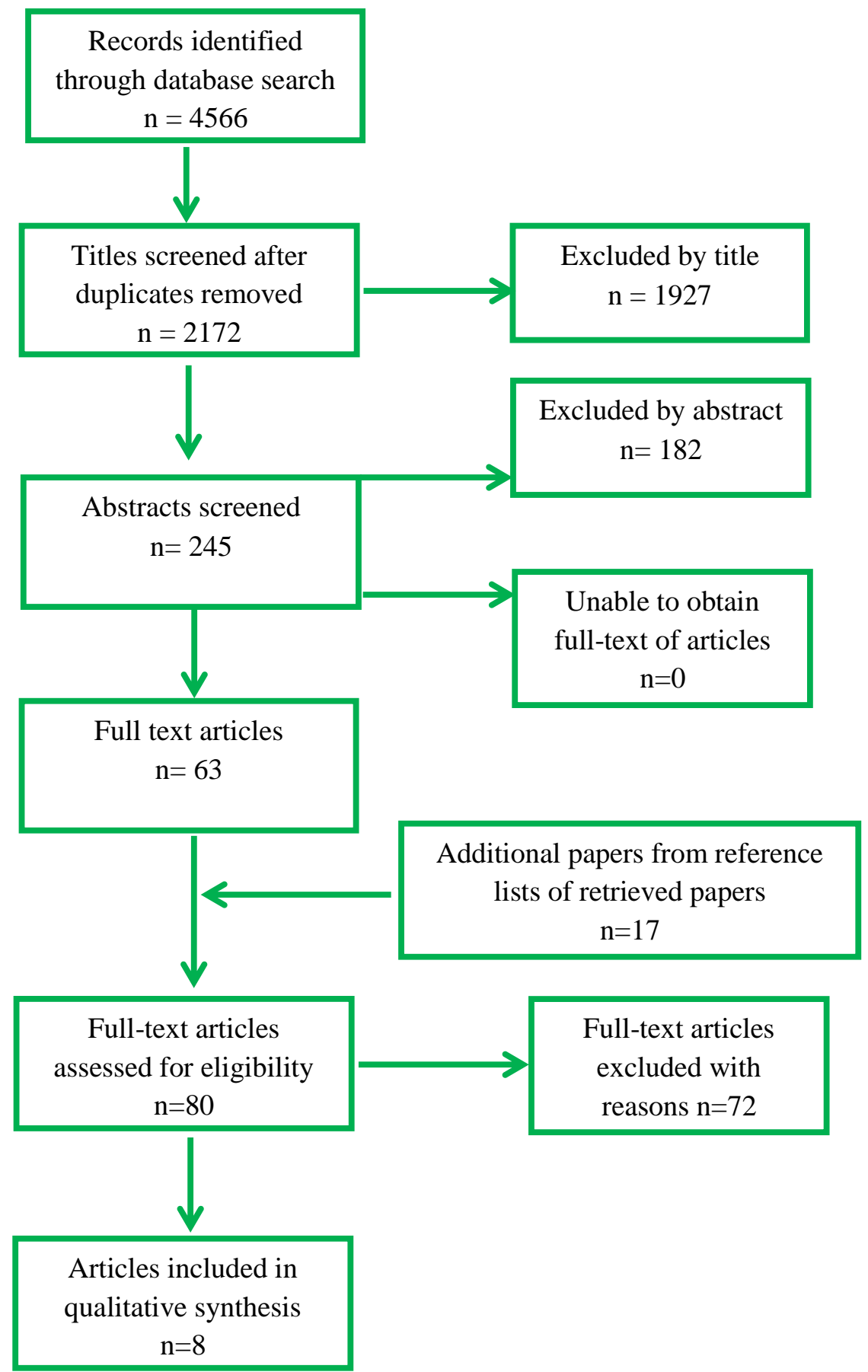

This article is protected by copyright. All rights reserved. 
Table 1: Risk of bias

\begin{tabular}{|l|l|l|l|l|l|l|}
\hline Study & Treatment & $\begin{array}{l}\text { Overall risk } \\
\text { of bias }\end{array}$ & $\begin{array}{l}\text { Risk of } \\
\text { selection bias }\end{array}$ & $\begin{array}{l}\text { Risk of } \\
\text { performance bias }\end{array}$ & $\begin{array}{l}\text { Risk of } \\
\text { attrition bias }\end{array}$ & $\begin{array}{l}\text { Risk of detection / } \\
\text { measurement bias }\end{array}$ \\
\hline Burmester et al. (23) & adalimumab & High & Low & Low & High & High \\
\hline Kimball et al. (20) & etanercept & High & Low & Low & Very high & High \\
\hline Leonardi et al. (24) & adalimumab & High & Low & Low & High & High \\
\hline Menter et al. (21) & infliximab & High & Low & Low & Very high & Low \\
\hline Papp et al. (25) & etanercept & High & Low & Low & Very high & High \\
\hline Papp et al. (22) & ustekinumab & High & Low & Low & High & High \\
\hline Pariser et al. (26) & etanercept & High & Low & Low & High & High \\
\hline van Lumig et al. (19) & TNFi & High & High & Low & High & High \\
\hline
\end{tabular}

TNFi: tumor necrosis factor inhibitor.

This article is protected by copyright. All rights reserved. 
Table 2: Confounding factors included in analysis of cancer risk

\begin{tabular}{|c|c|c|c|c|c|c|c|c|c|c|}
\hline \multirow[b]{2}{*}{ Study } & \multicolumn{6}{|c|}{ All cancers } & \multicolumn{2}{|l|}{ Skin cancers } & \multicolumn{2}{|c|}{$\begin{array}{l}\text { Solid tumours and } \\
\text { Lymphoma }\end{array}$} \\
\hline & Age & Sex & $\begin{array}{l}\text { Previous } \\
\text { cancers }\end{array}$ & $\begin{array}{l}\text { Previous } \\
\text { systemic tx }\end{array}$ & $\begin{array}{l}\text { Previous } \\
\text { biologic tx }\end{array}$ & $\begin{array}{l}\text { BMI or } \\
\text { obesity }\end{array}$ & $\begin{array}{l}\text { Previous } \\
\text { phototherapy }\end{array}$ & $\begin{array}{l}\text { Skin type/ } \\
\text { ethnicity }\end{array}$ & Smoking & \begin{tabular}{|l|} 
Alcohol \\
excess
\end{tabular} \\
\hline Burmester et al. (23) & $\checkmark$ & $\checkmark$ & $\mathbf{X}$ & $\mathbf{X}$ & $?$ & $\mathbf{X}$ & $?$ & $\mathbf{X}$ & $\mathbf{X}$ & $\mathbf{X}$ \\
\hline Kimball et al. (20) & $\checkmark$ & $\checkmark$ & $\mathbf{X}$ & $\mathbf{X}$ & $?$ & $\mathbf{X}$ & $\mathbf{X}$ & $\mathbf{X}$ & $\mathbf{X}$ & $\mathbf{X}$ \\
\hline Leonardi et al. (24) & $\checkmark$ & $\checkmark$ & $\mathbf{X}$ & $\mathbf{X}$ & $\mathbf{X}$ & $\mathbf{X}$ & $?$ & $\mathbf{X}$ & $\mathbf{X}$ & $\mathbf{X}$ \\
\hline Menter et al. (21) & $\checkmark$ & $\checkmark$ & $\checkmark$ excluded & $\mathbf{X}$ & $\mathbf{X}$ & $\mathbf{X}$ & $\mathbf{N} / \mathbf{A}^{2}$ & $\mathrm{~N} / \mathrm{A}^{2}$ & $\mathbf{X}$ & $\mathbf{X}$ \\
\hline Papp et al. (22) & $\checkmark$ & $\checkmark$ & $\mathbf{X}$ & $\mathbf{X}$ & $\mathbf{X}$ & $\mathbf{X}$ & $\mathbf{X}$ & $\checkmark$ & $\mathbf{X}$ & $\mathbf{X}$ \\
\hline Papp et al. (25) & $\checkmark$ & $\checkmark$ & $\mathbf{X}$ & $\mathbf{X}$ & $?$ & $\mathbf{X}$ & $\mathbf{X}$ & $\mathbf{X}$ & $\mathbf{X}$ & $\mathbf{X}$ \\
\hline Pariser et al. (26) & $?$ & $?$ & $\mathbf{X}$ & $\mathbf{X}$ & $?$ & $\mathbf{X}$ & $\mathbf{X}$ & $\mathbf{X}$ & $\mathbf{X}$ & $\mathbf{X}$ \\
\hline van Lumig et al. (19) & $\checkmark$ & $\checkmark$ & $\checkmark$ & $\sqrt{ }^{3}$ & $\checkmark$ & $\mathbf{X}$ & $\mathbf{X}$ & Partly $^{4}$ & $\mathbf{X}$ & $\mathbf{X}$ \\
\hline
\end{tabular}

$\checkmark$ included; X not included; ? unclear whether included.

BMI: body mass index; N/A: not applicable; tx: treatment. ${ }^{1}$ Including broad-band ultraviolet B (UVB), narrow-band UVB, and systemic and topical psoralen and ultraviolet A (PUVA); ${ }^{2}$ Study adjusted for race, but it did not look at incidence of skin cancers; ${ }^{3}$ Including ciclosporin, methotrexate, and corticosteroids; ${ }^{4}$ The intervention and comparison groups are from the same area (Netherlands) and same time period. The authors also expect that background degree of sun exposure related to latitude and skin cancer trends are similar for both groups.

This article is protected by copyright. All rights reserved. 
Table 3: Study Characteristics

\begin{tabular}{|c|c|c|c|c|}
\hline Study; design & Intervention group & Baseline characteristics and exposures & Comparison & Follow-up \\
\hline $\begin{array}{l}\text { Burmester et } \\
\text { al. (23); RCTs } \\
\text { \& OLE }\end{array}$ & $\begin{array}{l}\text { Data from } 13 \text { international } \\
\text { adalimumab trials (including } \\
\text { RCTs, open-label trials and } \\
\text { long-term extension studies) } \\
\text { Inclusion: Criteria varied per } \\
\text { study } \\
\text { Exclusion: Criteria varied per } \\
\text { study }\end{array}$ & $\begin{array}{l}\mathrm{n}=3010 \\
\text { Prior exposure to standard systemic or } \\
\text { phototherapy: not specified } \\
\text { Prior exposure to biologic therapy: not } \\
\text { specified } \\
\text { Age mean } 44.7 \text { years } \\
\text { Caucasian not specified } \\
\text { Weight mean not specified } \\
\text { Psoriatic arthritis: none (analyzed } \\
\text { separately) } \\
\text { Previous cancers: not specified } \\
\text { Exposure: median } 0.7 \text { years, maximum } \\
5.7 \text { years ( } 40.8 \% \text { had }>2 \text { years exposure, } \\
2.9 \% \text { had }>5 \text { years) }\end{array}$ & $\begin{array}{l}\text { General US population } \\
\text { For all cancers exc NMSC: } \\
\text { 5-year age-specific } \\
\text { incidence rates from the } \\
\text { NCI SEER database, } \\
\text { 1993-2001; age-and sex- } \\
\text { matched } \\
\text { For NMSC: 10-year age- } \\
\text { specific incidence rates } \\
\text { from 1977-1978 NCI } \\
\text { survey }\end{array}$ & $\begin{array}{l}\text { variable, up to } 5.7 \text { years; } \\
\text { median exposure } 0.7 \\
\text { years; adverse events } \\
\text { included follow-up for } 70 \\
\text { days after last dose }\end{array}$ \\
\hline $\begin{array}{l}\text { Kimball et al. } \\
\text { (20); } \\
\text { prospective } \\
\text { cohort }\end{array}$ & $\begin{array}{l}\text { Postmarketing safety } \\
\text { surveillance registry of } \\
\text { psoriasis patients on etanercept } \\
\text { in USA/Canada (OBSERVE- } \\
\text { 5); starting May } 2006 \\
\text { Inclusion: Patients with } \\
\text { plaque-type psoriasis for } \\
\text { whom etanercept therapy was } \\
\text { indicated } \\
\text { Exclusion: Initially, patients } \\
\text { were etanercept-naïve but later } \\
\text { protocol amendment allowed } \\
\text { patients with prior etanercept } \\
\text { treatment to enrol. Previous }\end{array}$ & $\begin{array}{l}\mathrm{n}=2510 \\
\text { Prior exposure to standard systemic or } \\
\text { phototherapy: not specified } \\
\text { Prior exposure to biologic therapy: } 664 \\
(26 \%) \text { had prior etanercept exposure } \\
\text { Age mean } 46.3 \text { years } \\
\text { Caucasian } 81.8 \% \\
\text { Weight mean not specified } \\
\text { Psoriatic arthritis } 18.5 \% \\
\text { Previous cancers: not specified } \\
\text { Exposure: mean(SD) was } 1.7(1.1) \text { years } \\
\text { and } 1.6(1.1) \text { years in the prior etanercept } \\
\text { and etanercept-naive groups, } \\
\text { respectively }\end{array}$ & $\begin{array}{l}\text { US patients who received } \\
\text { non-biologic systemic } \\
\text { therapies (methotrexate, } \\
\text { cyclosporine) for other } \\
\text { inflammatory conditions in } \\
2006 \\
\text { From medical and drug } \\
\text { insurance claims } \\
\text { databases; using incidence } \\
\text { rates based on person-time } \\
\text { of observation; age- and } \\
\text { sex-matched }\end{array}$ & $\begin{array}{l}7 \text { years ( } 8 \text { years for some } \\
\text { outcomes) }\end{array}$ \\
\hline
\end{tabular}

This article is protected by copyright. All rights reserved. 


\begin{tabular}{|c|c|c|c|c|}
\hline & $\begin{array}{l}\text { treatment with any other TNFi } \\
\text { therapies. }\end{array}$ & & & \\
\hline $\begin{array}{l}\text { Leonardi et al. } \\
\text { (24); RCTs \& } \\
\text { OLE }\end{array}$ & $\begin{array}{l}\text { Data from } 13 \text { international } \\
\text { adalimumab RCTs and their } \\
\text { OLE studies (BELIEVE, } \\
\text { PRIDE, M10-238, M10-405, } \\
\text { M02-528, M02-529, M02-538, } \\
\text { M03-596, M03-658, M04-688, } \\
\text { M04-702, REVEAL, } \\
\text { CHAMPION); data pooled up } \\
\text { to Nov 2009 } \\
\text { Inclusion: adults with } \\
\text { moderate-to-severe plaque- } \\
\text { type psoriasis. Exact criteria } \\
\text { varied per study. } \\
\text { Exclusion: prior exposure to } \\
\text { any TNFi therapy, except in } \\
\text { extension trials (of } \\
\text { adalimumab RCTs), and in } \\
\text { M10-238 and PRIDE (all prior } \\
\text { TNFi therapy was permitted). }\end{array}$ & $\begin{array}{l}\mathrm{n}=3010 \\
\text { Prior exposure to standard systemic or } \\
\text { phototherapy: not specified } \\
\text { Prior exposure to biologic therapy: not } \\
\text { specified } \\
\text { Age mean } 44.7 \text { years (SD 12.7) } \\
\text { Caucasian } 87.5 \% \\
\text { Weight mean } 89.0 \mathrm{~kg} \text { (SD 22) } \\
\text { Psoriatic arthritis } 28.6 \% \text { (out of 2034) } \\
\text { Previous cancers: not specified } \\
\text { Exposure: varied per study }\end{array}$ & $\begin{array}{l}\text { General US population } \\
\text { For all cancers exc NMSC: } \\
\text { rates from the NCI SEER } \\
\text { database for 1993-2001; } \\
\text { age- and sex-matched } \\
\text { For NMSC: rates from the } \\
\text { 1977-8 NCI Survey. }\end{array}$ & $\begin{array}{l}\text { varied from } 12 \text { weeks to } \\
>5 \text { years } \\
\text { (adverse events that } \\
\text { occurred up to } 70 \text { days } \\
\text { after the final dose of } \\
\text { adalimumab were } \\
\text { analysed) }\end{array}$ \\
\hline $\begin{array}{l}\text { Menter et al. } \\
\text { (21); RCTs }\end{array}$ & $\begin{array}{l}\text { Data from three international } \\
\text { infliximab RCTs (SPIRIT, } \\
\text { EXPRESS, EXPRESS II); } \\
\text { published 2004-2007 } \\
\text { Inclusion: Adults ( } \geq 18 \text { years) } \\
\text { with moderate-to-severe } \\
\text { plaque psoriasis, with PASI } \\
>12 \text { and BSA at least } 10 \% \\
\text { Exclusion: nonplaque forms of } \\
\text { psoriasis, recent or recurrent } \\
\text { serious infections; }\end{array}$ & $\begin{array}{l}\mathrm{n}=1373 \text { (and } 334 \text { placebo); baseline data } \\
\text { below is from } 1462 \text { patients } \\
\text { Prior exposure to standard systemic or } \\
\text { phototherapy: UVB } 54.3 \% \text {, PUVA } \\
34.8 \% \text {, methotrexate } 39.3 \% \text {, acitrecin } \\
19.9 \% \text {, cyclosporin } 19.7 \% \\
\text { Prior exposure to biologic therapy: } \\
18.1 \% \\
\text { Age mean } 43.8 \text { years (SD 12.5) } \\
\text { Caucasian } 92.9 \% \\
\text { Weight mean } 90.8 \text { (SD } 22.3 \mathrm{~kg} \text { ) }\end{array}$ & $\begin{array}{l}\text { General US population } \\
\text { For all cancers exc NMSC: } \\
\text { NCI SEER database; age-, } \\
\text { race-, sex-matched }\end{array}$ & $\begin{array}{l}30 \text { weeks }(\mathrm{N}=248) \text { and } \\
50 \text { weeks }(\mathrm{N}=1209)\end{array}$ \\
\hline
\end{tabular}

This article is protected by copyright. All rights reserved. 


\begin{tabular}{|c|c|c|c|c|}
\hline & $\begin{array}{l}\text { lymphoproliferative disease; } \\
\text { cancer or history of cancer } \\
\text { within } 5 \text { years of screening } \\
\text { (other than previously excised, } \\
\text { nonrecurrent BCC); severe } \\
\text { systemic disease; congestive } \\
\text { heart failure, SLE, } \\
\text { demyelinating disease; active } \\
\text { or latent TB. }\end{array}$ & $\begin{array}{l}\text { Psoriatic arthritis } 28.9 \% \\
\text { Previous cancers: not specified } \\
\text { Exposure: varied per study }\end{array}$ & & \\
\hline $\begin{array}{l}\text { Papp et al. (25) } \\
\text { RCTs \& OLE }\end{array}$ & $\begin{array}{l}\text { Data from two Canadian } \\
\text { etanercept trials (starting May } \\
2002 \text { and June 2003) and their } \\
\text { OLEs. } \\
\text { Inclusion: Patients with } \\
\text { plaque-type psoriasis. Specific } \\
\text { criteria varied per study. } \\
\text { Exclusion: Criteria varied per } \\
\text { study. }\end{array}$ & $\begin{array}{l}\mathrm{n}=506 \\
\text { Prior exposure to standard systemic or } \\
\text { phototherapy: } 71.9 \% \text { phototherapy } \\
\text { Prior exposure to biologic therapy: not } \\
\text { specified } \\
\text { Age mean } 46.0, \text { SD } 11.7 \\
\text { Caucasian } 96.4 \% \\
\text { Weight mean } 90.1 \mathrm{~kg} \text {, SD } 20.6 \\
\text { Psoriatic arthritis not specified } \\
\text { Previous cancers: not specified } \\
\text { Exposure: varied per study }\end{array}$ & $\begin{array}{l}\text { General US population } \\
\text { For all cancers exc NMSC: } \\
\text { rates from the NCI SEER } \\
\text { database for 1992-2002; } \\
\text { age-and sex- matched } \\
\text { For NMSC: Minnesota and } \\
\text { Arizona databases; age- } \\
\text { and sex-matched }\end{array}$ & $\begin{array}{l}\text { Up to } 54 \text { months } \\
\text { [449 }(88.7 \%) \text { patients } \\
\text { treated for at least } 12 \\
\text { months, } 398(78.7 \%) \text { at } \\
\text { least } 24 \text { months, } 144 \\
(28.5 \%) \text { at least } 36 \\
\text { months, and } 108(21.3 \%) \\
\text { at least } 48 \text { months; } 60 \\
\text { patients remained on } \\
\text { study after } 48 \text { months, up } \\
\text { to an additional } 6 \\
\text { months] }\end{array}$ \\
\hline $\begin{array}{l}\text { Papp et al. (22) } \\
\text { RCTs }\end{array}$ & $\begin{array}{l}\text { Long-term safety data from } 4 \\
\text { RCTs using ustekinumab } \\
\text { (phase II, PHOENIX 1, } \\
\text { PHOENIX2, ACCEPT); } \\
\text { published between } 2007-2010 \\
\text { Inclusion: adults ( } \geq 18 \text { years) } \\
\text { with moderate-to-severe } \\
\text { psoriasis. Exact criteria varied } \\
\text { per study. } \\
\text { Exclusion: Criteria varied per } \\
\text { study. }\end{array}$ & $\begin{array}{l}\mathrm{n}=3117 \\
\text { Prior exposure to standard systemic or } \\
\text { phototherapy: PUVA } 27.4 \% \text {, UVB } \\
56.1 \% \text {, ciclosporin } 13.7 \% \text {, methotrexate } \\
35.3 \% \\
\text { Prior exposure to biologic therapy: } \\
26.3 \% \text { etanercept/infliximab/ } \\
\text { adalimumab } \\
\text { Age mean } 45.6 \text { years (SD } 12.3 \text { ) } \\
\text { Caucasian } 92.2 \% \\
\text { Weight: } 47.8 \% \mathrm{BMI} \geq 30,33.0 \% \mathrm{BMI}\end{array}$ & $\begin{array}{l}\text { General US population } \\
\text { For all cancers exc NMSC: } \\
\text { rates from the NCI SEER } \\
\text { database; age-and sex- and } \\
\text { race-matched }\end{array}$ & 5 years \\
\hline
\end{tabular}

This article is protected by copyright. All rights reserved. 


\begin{tabular}{|c|c|c|c|c|}
\hline & & $\begin{array}{l}\geq 25-30,19.1 \% \text { BMI }<25 \\
\text { Psoriatic arthritis } 27.5 \% \\
\text { Previous cancers: not specified } \\
\text { Exposure: varied per study; at least } 4 \\
\text { years in } 1482 \text { patients }\end{array}$ & & \\
\hline $\begin{array}{l}\text { Pariser et al. } \\
(26) ; \text { RCT }\end{array}$ & $\begin{array}{l}\text { Analysis of } 7 \text { international } \\
\text { etanercept psoriasis trials and } \\
\text { extension studies }(160032, \\
160039,160042,20030117, \\
20030115,20030190, \\
20040216) \text {; published between } \\
\text { 2003-2010 } \\
\text { Inclusion: : Adults ( } \geq 18 \text { years) } \\
\text { with moderate-to-severe } \\
\text { plaque-type psoriasis and } \\
>10 \% \text { BSA } \\
\text { Exclusion: Criteria varied per } \\
\text { study. }\end{array}$ & $\begin{array}{l}\mathrm{n}=4410 \\
\text { Prior exposure to standard systemic or } \\
\text { phototherapy: not specified } \\
\text { Prior exposure to biologic therapy: not } \\
\text { specified } \\
\text { Age mean } 45.4 \text { years } \\
\text { Caucasian } 86.6 \% \\
\text { Weight mean } 90.7 \mathrm{~kg} \\
\text { Psoriatic arthritis not specified } \\
\text { Previous cancers: not specified } \\
\text { Exposure: varied per study }\end{array}$ & $\begin{array}{l}\text { General US population } \\
\text { For all cancers exc NMSC: } \\
\text { NCI SEER database for } \\
1992-2003 \\
\text { For NMSC: Minnesota and } \\
\text { Arizona databases }\end{array}$ & $\begin{array}{l}12 \text { weeks to } 144 \text { weeks } \\
\text { Events occurring } \\
\text { between the first dose } \\
\text { and within } 30 \text { days after } \\
\text { the last dose of } \\
\text { etanercept were included. }\end{array}$ \\
\hline $\begin{array}{l}\text { van Lumig et } \\
\text { al. (19); } \\
\text { prospective } \\
\text { cohort }\end{array}$ & $\begin{array}{l}\text { Patients on etanercept, } \\
\text { adalimumab and/or infliximab } \\
\text { at two medical centers in the } \\
\text { Netherlands; during February } \\
2005 \text { to November } 2011 \\
\text { Inclusion: patients with plaque } \\
\text { psoriasis initiated on } \\
\text { etanercept, adalimumab and/or } \\
\text { infliximab at } 2 \text { hospitals, with } \\
\text { a follow-up of at least } 1 \text { year } \\
\text { after the start of TNFi therapy } \\
\text { and enrolled in their respective } \\
\text { registries }\end{array}$ & $\begin{array}{l}\mathrm{n}=280 \\
\text { Prior exposure to standard systemic or } \\
\text { phototherapy: phototherapy 99\% (of } \\
\text { 279), UVB 92\% (of 276), PUVA 58\% } \\
\text { (of 275), methotrexate 96\%, ciclosporin } \\
78 \% \text {, prednisolone 9\%, azathioprine } 1 \% \\
\text { Prior exposure to biologic therapy: not } \\
\text { specified } \\
\text { Age mean } 46.8 \text { years (SD 11.9) } \\
\text { Caucasian not specified } \\
\text { Weight mean not specified } \\
\text { Psoriatic arthritis } 28 \% \\
\text { Previous cancers: } 2.1 \% \text { NMSC (and }\end{array}$ & $\begin{array}{l}\text { All rheumatoid arthritis } \\
\text { patients from same region } \\
\text { treated with the same TNFi } \\
\text { agents; between } 2001 \text { and } \\
\text { November } 2011\end{array}$ & $\begin{array}{l}\text { median } 4.8 \text { years (range } \\
1.0-9.3 \text { ) }\end{array}$ \\
\hline
\end{tabular}

This article is protected by copyright. All rights reserved. 


\begin{tabular}{|l|l|l|l|l|}
\hline & Exclusion: not specified & $\begin{array}{l}1.1 \% \text { in RA group, } \mathrm{p}=0.4) \\
\text { Exposure: median 4.1 (0.1-14.9) }\end{array}$ & \\
\hline
\end{tabular}

BCC: basal cell carcinoma; BSA: body surface area; kg: kilogram; OLE: open-label extension; n: number of patients; NCI: National Cancer Institute; NMSC: non-melanoma skin cancer; PASI: Psoriasis Area Severity Index; PUVA: psoralen and ultraviolet A; RA: rheumatoid arthritis; RCTs: randomized controlled trials; SD: standard deviation; SEER: Surveillance, Epidemiology, and End Results database; SLE: systemic lupus erythematosus; TB: tuberculosis; TNFi: tumor necrosis factor inhibitor; US: United States; UVB: ultraviolet B.

This article is protected by copyright. All rights reserved. 
Table 4: Summary of evidence

\begin{tabular}{|c|c|c|c|c|c|}
\hline Outcome & Intervention & Comparison & $\begin{array}{l}\text { No of } \\
\text { Participants, } \\
\text { N; } \\
\text { Follow-up }\end{array}$ & $\begin{array}{l}\text { Patients with } \\
\text { events, } \mathbf{N} \text {; } \\
\text { [number of } \\
\text { events, } N \text { ] }\end{array}$ & $\begin{array}{l}\text { Relative } \\
\text { effect } \\
(95 \% \text { CI })\end{array}$ \\
\hline \multicolumn{6}{|c|}{ Any cancers } \\
\hline \multirow{7}{*}{$\begin{array}{l}\text { Any } \\
\text { cancers } \\
\text { excluding } \\
\text { NMSC }\end{array}$} & $\begin{array}{l}\text { adalimumab } \\
\text { (23) }\end{array}$ & $\begin{array}{l}\text { general US } \\
\text { population }\end{array}$ & $\begin{array}{l}3010 ; 0.5 \text { years } \\
\text { (median), } 5.5 \\
\text { years (max) }\end{array}$ & {$[9]^{b}$} & $\begin{array}{l}\text { SIR 0.96 } \\
(0.65-1.36)^{c}\end{array}$ \\
\hline & $\begin{array}{l}\text { adalimumab } \\
\text { (24) }\end{array}$ & $\begin{array}{l}\text { general US } \\
\text { population }\end{array}$ & $\begin{array}{l}3010 ;>0.5 \\
\text { years }(\text { median}), \\
>5 \text { years }(\max )\end{array}$ & {$[35]$} & $\begin{array}{l}\text { SIR 0.90 } \\
(0.60-1.29)^{\mathrm{c}}\end{array}$ \\
\hline & $\begin{array}{l}\text { etanercept } \\
(20)\end{array}$ & $\begin{array}{l}\text { Patients on } \\
\text { methotrexate } \\
\text { or ciclosporin }\end{array}$ & $\begin{array}{l}2510 ; 7 \text { years } \\
\text { (all patients) }\end{array}$ & 59 & $\begin{array}{l}\text { SIR } 0.78 \\
(0.59-1.00)\end{array}$ \\
\hline & $\begin{array}{l}\text { etanercept } \\
(25)\end{array}$ & $\begin{array}{l}\text { general US } \\
\text { population }\end{array}$ & $\begin{array}{l}\text { 506; } 2-3 \text { years } \\
(\text { median }), 4.5 \\
\text { years }(\max )\end{array}$ & 6 [7] & $\begin{array}{l}\text { SIR 0.91 } \\
(0.37-1.88)\end{array}$ \\
\hline & $\begin{array}{l}\text { etanercept } \\
(26)\end{array}$ & $\begin{array}{l}\text { general US } \\
\text { population }\end{array}$ & $\begin{array}{l}\text { 4410; } 3 \text { years } \\
(\max )\end{array}$ & {$[30]$} & $\begin{array}{l}\text { SIR 1.15 } \\
(0.78-1.64)\end{array}$ \\
\hline & $\begin{array}{l}\text { infliximab } \\
(21)\end{array}$ & $\begin{array}{l}\text { general US } \\
\text { population }\end{array}$ & $\begin{array}{l}\text { 1373; 1 year } \\
\text { (median), 0.5-1 } \\
\text { years (range) }\end{array}$ & 2 & $\begin{array}{l}\text { SIR 0.39 } \\
(0.05-1.42)\end{array}$ \\
\hline & $\begin{array}{l}\text { ustekinumab } \\
\text { (22) }\end{array}$ & $\begin{array}{l}\text { general US } \\
\text { population }\end{array}$ & $\begin{array}{l}3117 ; 5 \text { years } \\
\text { (all patients) }\end{array}$ & 54 & $\begin{array}{l}\text { SIR 0.98 } \\
(0.74-1.29)\end{array}$ \\
\hline \multicolumn{6}{|c|}{ Skin cancers } \\
\hline \multirow[t]{4}{*}{ NMSC } & $\begin{array}{l}\text { adalimumab } \\
\text { (23) }\end{array}$ & $\begin{array}{l}\text { general US } \\
\text { population }\end{array}$ & $\begin{array}{l}3010 ; 0.5 \text { years } \\
\text { (median), } 5.5 \\
\text { years (max) }\end{array}$ & {$[40]$} & $\begin{array}{l}\text { SIR 1.76 } \\
(1.26-2.39)^{c, d}\end{array}$ \\
\hline & $\begin{array}{l}\text { adalimumab } \\
\text { (24) }\end{array}$ & $\begin{array}{l}\text { general US } \\
\text { population }\end{array}$ & $\begin{array}{l}3010 ;>0.5 \\
\text { years }(\text { median }), \\
>5 \text { years }(\max )\end{array}$ & {$[34]$} & $\begin{array}{l}\text { SIR 1.51 } \\
(1.04-2.11)^{c, d}\end{array}$ \\
\hline & TNFi (19) & $\begin{array}{l}\text { Rheumatoid } \\
\text { Arthritis } \\
\text { patients on } \\
\text { TNFi }\end{array}$ & $\begin{array}{l}280 ; 5 \text { years } \\
\text { (median) } 1-9.5 \\
\text { (range) }\end{array}$ & $11[38]$ & $\begin{array}{l}\text { HR 6.0 (1.6- } \\
22.4) \\
\text { RR 5.5 (2.2- } \\
13.4)\end{array}$ \\
\hline & $\begin{array}{l}\text { etanercept } \\
(20)\end{array}$ & $\begin{array}{l}\text { general US } \\
\text { population on } \\
\text { MTX or } \\
\text { ciclosporin }\end{array}$ & $\begin{array}{l}2510 ; 7 \text { years } \\
\text { (all patients) }\end{array}$ & 66 & $\begin{array}{l}\text { SIR 0.54 } \\
(0.42-0.69)\end{array}$ \\
\hline \multirow[t]{2}{*}{$\mathrm{BCC}$} & $\begin{array}{l}\text { etanercept } \\
(25)\end{array}$ & $\begin{array}{l}\text { general US } \\
\text { population }\end{array}$ & $\begin{array}{l}\text { 506; } 2-3 \text { years } \\
\text { (median), } 4.5 \\
\text { years }(\max )\end{array}$ & 9 [12] & $\begin{array}{l}\text { SIR 0.52 } \\
(0.23-1.03)^{\mathrm{e}}\end{array}$ \\
\hline & $\begin{array}{l}\text { etanercept } \\
(26)\end{array}$ & $\begin{array}{l}\text { general US } \\
\text { population }\end{array}$ & $\begin{array}{l}4410 ; 3 \text { years } \\
(\max )\end{array}$ & $28[31]$ & $\begin{array}{l}\text { SIR 0.55 } \\
(0.37-0.80)^{\mathrm{e}}\end{array}$ \\
\hline SCC & $\begin{array}{l}\text { adalimumab } \\
\text { (24) }\end{array}$ & $\begin{array}{l}\text { general US } \\
\text { population }\end{array}$ & $\begin{array}{l}3010 ;>0.5 \\
\text { years (median), }\end{array}$ & {$[14]$} & $\begin{array}{l}\text { SIR 3.84 } \\
(1.54-\end{array}$ \\
\hline
\end{tabular}

This article is protected by copyright. All rights reserved. 


\begin{tabular}{|c|c|c|c|c|c|}
\hline & & & $>5$ years $(\max )$ & & 7.92) $)^{c, d, f}$ \\
\hline & $\begin{array}{l}\text { etanercept } \\
(25)\end{array}$ & $\begin{array}{l}\text { general US } \\
\text { population }\end{array}$ & $\begin{array}{l}506 ; 2-3 \text { years } \\
(\text { median), } 4.5 \\
\text { years }(\max )\end{array}$ & 4 & $\begin{array}{l}\text { SIR 1.08 } \\
(0.29-2.76)^{\mathrm{e}} \\
\text { SIR 2.68 } \\
(0.72-6.87)^{\mathrm{g}}\end{array}$ \\
\hline & $\begin{array}{l}\text { etanercept } \\
\text { (26) }\end{array}$ & $\begin{array}{l}\text { general US } \\
\text { population }\end{array}$ & $\begin{array}{l}4410 ; 3 \text { years } \\
(\max )\end{array}$ & $22[25]$ & 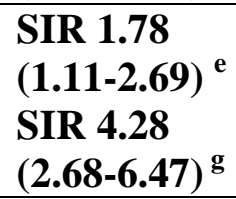 \\
\hline Melanoma & $\begin{array}{l}\text { ustekinumab } \\
\text { (22) }\end{array}$ & $\begin{array}{l}\text { general US } \\
\text { population }\end{array}$ & $\begin{array}{l}3117 ; 5 \text { years } \\
\text { (all patients) }\end{array}$ & 6 & $\begin{array}{l}\text { SIR 1.42 } \\
(0.52-3.09)\end{array}$ \\
\hline \multicolumn{6}{|c|}{ Solid Cancers and Lymphoma } \\
\hline Prostate & \multirow{3}{*}{$\begin{array}{l}\text { ustekinumab } \\
\text { (22) }\end{array}$} & \multirow{3}{*}{$\begin{array}{l}\text { general US } \\
\text { population }\end{array}$} & \multirow{3}{*}{$\begin{array}{l}3117 ; 5 \text { years } \\
\text { (all patients) }\end{array}$} & \multirow{3}{*}{$\begin{array}{l}14 \\
5 \\
4\end{array}$} & SIR 1.21 \\
\hline Colorectal & & & & & $(0.66-2.04)$ \\
\hline Breast & & & & & $\begin{array}{l}\text { SIR } 0.99 \\
(0.32-2.31) \\
\text { SIR } 0.62 \\
(0.17-1.58)\end{array}$ \\
\hline \multirow[t]{3}{*}{ Lymphoma } & $\begin{array}{l}\text { adalimumab } \\
\text { (23) }\end{array}$ & $\begin{array}{l}\text { general US } \\
\text { population }\end{array}$ & $\begin{array}{l}3010 ; \text { median } \\
0.5 \text { years, max } \\
5.5 \text { years }\end{array}$ & 1 & $\begin{array}{l}\text { SIR 0.63 } \\
(0.01-3.49)\end{array}$ \\
\hline & $\begin{array}{l}\text { etanercept } \\
(20)\end{array}$ & $\begin{array}{l}\text { general US } \\
\text { population on } \\
\text { MTX or } \\
\text { ciclosporin }\end{array}$ & $\begin{array}{l}\text { 2510; } 7 \text { years } \\
\text { (all patients) }\end{array}$ & 2 & $\begin{array}{l}\text { SIR 0.26 } \\
(0.03-0.95)\end{array}$ \\
\hline & $\begin{array}{l}\text { ustekinumab } \\
(22)\end{array}$ & $\begin{array}{l}\text { general US } \\
\text { population }\end{array}$ & $\begin{array}{l}3117 ; 5 \text { years } \\
\text { (all patients) }\end{array}$ & 2 & $\begin{array}{l}\text { SIR 0.80 } \\
(0.10-2.91)\end{array}$ \\
\hline
\end{tabular}

BCC: basal cell carcinoma; CI: confidence interval; HR: hazard ratio; max: maximum length; NMSC: non-melanoma skin cancer; N: number of patients; RR: risk ratio; SCC: squamous cell carcinoma; SIR: standardized incidence ratio; TNFi: tumor necrosis factor inhibitor; US: United States. ${ }^{a}$ Estimated to the nearest half-year. ${ }^{b}$ Not clear from paper whether solid cancers were counted (the 9 cancers were only lymphoma and melanoma). ${ }^{c}$ Based on incidence of cancers, not patients with event; ${ }^{\mathrm{d}}$ Using the 1977-8 National Cancer Institute study database; ${ }^{\mathrm{e}}$ Using the Arizona registry; ${ }^{\mathrm{f}}$ Not significant if Arizona or Minnesota registries are used. ${ }^{\mathrm{g}}$ Using the Minnesota registry.

This article is protected by copyright. All rights reserved. 